\title{
Interaksi Genotipe $\times$ Musim Karakter Percabangan Malai Tiga Genotipe Padi Sawah
}

\section{Genotype $\times$ Season Interaction of Three Rice Genotypes on Panicle Branching Traits}

\author{
Tri Hastini ${ }^{1}$, Willy Bayuardi Suwarno ${ }^{2}$, Munif Ghulamahdi ${ }^{2}$, dan Hajrial Aswidinnoor ${ }^{2 *}$ \\ 'Balai Pengkajian Teknologi Pertanian Jawa Barat, Badan Penelitian dan Pengembangan Pertanian \\ Kementerian Pertanian, Jl. Kayuambon No. 80 Lembang, Bandung Barat 40391, Indonesia \\ ${ }^{2}$ Departemen Agronomi dan Hortikultura, Fakultas Pertanian, Institut Pertanian Bogor \\ (Bogor Agricultural University), Jl. Meranti, Kampus IPB Darmaga, Bogor 16680, Indonesia
}

Diterima 27 Februari 2020/Disetujui 14 April 2020

\begin{abstract}
Rice panicle branching architecture is an important trait affecting yield, but its responses across different seasons have not been extensively studied yet. The aim of this study was to evaluate the panicle branching responses of fifteen rice genotypes on different seasons. This study was conducted from April 2017 to March 2018 at Babakan Experimental Station, IPB University, Dramaga, Bogor. Fifteen genotypes as treatments were grown in the dry and wet seasons to study the genotypes $\times$ seasons interaction effects on panicle branching. The experiment was laid out in a randomized complete block design with four replicates. Individual analysis and combined analyses over seasons were performed. The results revealed that the genotype, season, and genotype $\times$ seasons had significant effects on panicle length, number of primary branches, length of primary branches, and length of secondary branches. The results of the study may be useful for rice breeders in conducting selection based on panicle branching.
\end{abstract}

Keywords: dry and wet season, genotypes $\times$ seasons, rice breeding

\section{ABSTRAK}

Percabangan malai merupakan salah satu kunci penentu hasil padi, namun keragaannya antar musim belum banyak dipelajari hingga saat ini. Penelitian ini bertujuan untuk mendapatkan informasi tentang interaksi genotipe $\times$ musim karakter percabangan malai padi. Percobaan dilaksanakan dari bulan April 2017 sampai dengan Maret 2018, di Kebun Percobaan IPB Babakan, Dramaga, Bogor. Lima belas genotipe padi sawah sebagai perlakuan ditanam pada musim kemarau dan musim hujan untuk mempelajari interaksi genotipe $\times$ musim. Percobaan ditata dalam rancangan acak kelompok lengkap dengan empat ulangan. Analisis yang dilakukan adalah analisis ragam per musim dan analisis ragam gabungan antar musim. Hasil percobaan menunjukkan bahwa genotipe, musim, dan interaksi genotipe $\times$ musim berpengaruh nyata pada karakter panjang malai, jumlah cabang primer, panjang cabang primer, dan panjang cabang sekunder. Informasi yang diperoleh dari hasil penelitian ini dapat bermanfaat bagi pemulia padi dalam melakukan seleksi pada karakter percabangan malai.

Kata kunci: genotipe $\times$ musim, musim kemarau, musim hujan, pemuliaan padi

\section{PENDAHULUAN}

Penampilan suatu karakter dipengaruhi oleh faktor genetik, lingkungan serta interaksi genotipe $\times$ lingkungan. Interaksi genotipe $\times$ lingkungan dapat terlihat dari perubahan perilaku genotipe pada lingkungan yang berbeda (Baye et al., 2011). Hasil percobaan Sumarno dan Sutisna (2010) menjelaskan bahwa terdapat varietas padi yang mempunyai hasil lebih tinggi pada musim kemarau (MK), lebih tinggi pada musim hujan (MH), dan terdapat genotipe yang tinggi pada kedua musim. Laenoi et al. (2018) menjelaskan bahwa

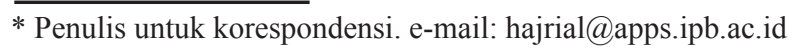

pengaruh musim sangat nyata terhadap kuantitas maupun kualitas hasil padi.

Pengujian hasil padi di Sukamandi pada tahun 1995 menunjukkan hasil pada MH lebih tinggi daripada MK. Pengujian multilokasi pada tahun 2001 di Jawa Tengah dan Jawa Barat menunjukkan bahwa varietas IR64 sebagai pembanding menunjukkan hasil lebih tinggi pada MK. Varietas hibrida dan Ciherang pada uji multilokasi tahun 2010 dan 2011 juga menunjukkan hasil yang lebih tinggi pada MK (Satoto et al., 2013). Islam et al. (2010) melaporkan bahwa rata-rata produktivitas dari tiga padi inbrida pada MH sebesar 6.79 ton ha ${ }^{-1}$, sedangkan pada MK 7.69 ton ha ${ }^{-1}$. Hasil penelitian Alam et al. (2013) memberikan informasi bahwa hasil padi pada MK lebih tinggi yaitu 8.4 ton ha ${ }^{-1}$ 
pada MK dan 5.3 ton ha-1 pada $\mathrm{MH}$, sedangkan Silva et al. (2017) melaporkan hasil padi mencapai 5.7 ton $\mathrm{ha}^{-1}$ pada MK dan 5.1 ton ha $^{-1}$ pada $\mathrm{MH}$.

Perbedaan hasil tersebut diduga disebabkan oleh faktor iklim dan cuaca. Musim hujan dicirikan dengan terjadinya penurunan suhu udara harian, lama penyinaran matahari yang lebih pendek, radiasi surya yang lebih rendah, curah hujan yang lebih tinggi (dalam satu dasarian lebih dari 50 $\mathrm{mm}$ dan diikuti oleh dasarian berikutnya), dan kondisi langit yang berawan, sedangkan pada MK terjadi kondisi yang sebaliknya (Satoto et al., 2013; Ulfah dan Sulistya, 2015). Suhu merupakan salah satu faktor yang sangat menentukan terjadinya perbedaan hasil padi antara $\mathrm{MH}$ dan $\mathrm{MK}$. Pengaruh suhu terhadap karakter bobot biji padi dilaporkan oleh Wu et al. (2016), bahwa pada suhu di atas $28^{\circ} \mathrm{C}$ tanggap genotipe sangat bervariasi pada karakter tersebut.

Hasil padi dipengaruhi oleh karakter percabangan malai. Ramadhan (2017) melaporkan terdapatnya korelasi positif antara panjang malai dengan panjang sumbu utama malai, jumlah gabah per malai, panjang cabang primer malai, dan jumlah gabah per cabang primer malai. Secara genetik, jumlah cabang primer dan panjang sekunder malai mempunyai heritabilitas yang tinggi ( $>50 \%$ ) dengan aksi gen aditif dan dikendalikan oleh banyak gen (Rahayu, 2018b). Karakter panjang malai, jumlah cabang primer, dan jumlah cabang sekunder dikendalikan oleh banyak gen (Ramadhan et al., 2018). Hastini (2019) menyatakan bahwa karakter cabang tersier malai dipengaruhi oleh banyak gen (poligenik) melalui aksi gen aditif dan epistasis komplementer. Pengaruh musim terhadap karakter percabangan malai belum dilaporkan secara lengkap, umumnya baru sebatas panjang malai dan jumlah gabah per malai. Kovi et al. (2011) menyatakan terdapatnya pengaruh interaksi genotipe $\times$ musim yang nyata pada karakter panjang malai, dan jumlah gabah total per malai pada genotipe padi indica Zhensan 97 dan Zhingzao 18. Jayaningsih (2019) menginformasikan bahwa terdapat interaksi genotipe $\times$ lingkungan pada karakter percabangan malai. Penelitian ini bertujuan untuk mengetahui pengaruh musim terhadap percabangan malai padi pada 15 perlakuan yang berasal dari tiga genotipe yang ditanam pada $\mathrm{MK}$ dan $\mathrm{MH}$.

\section{BAHAN DAN METODE}

Percobaan dilaksanakan di Kebun Percobaan IPB Babakan, Dramaga, Bogor pada bulan April 2017 sampai Maret 2018. Musim pertama merupakan MK dengan jumlah curah hujan $1414 \mathrm{~mm}$, suhu rata-rata bulanan $26.1{ }^{\circ} \mathrm{C}$, kelembapan $80 \%$, serta penyinaran matahari $71.83 \%$ (persentase lama penyinaran matahari terhadap panjang hari yang diukur menggunakan alat Campbell Stokes) (BPS Kabupaten Bogor, 2018). Musim kedua pada MH dengan jumlah curah hujan $1555 \mathrm{~mm}$, suhu $25.86^{\circ} \mathrm{C}$, kelembapan $85.2 \%$, serta penyinaran matahari $49.2 \%$. (BPS Kabupaten Bogor 2018; BPS Kabupaten Bogor, 2019).

Percobaan menggunakan materi genetik berasal dari tiga galur lanjut padi sawah yaitu IPB158-F-5, IPB180-F-12, dan IPB180-F-6-1-1. Lima malai dari masing-masing galur ditanam sebagai perlakuan (untuk mengetahui keragaman dalam galur), sehingga terdapat 15 perlakuan. Limabelas perlakuan tersebut yaitu IPB158-F-5(1), IPB158-F-5(2), IPB158-F-5(3), IPB158-F-5(4), IPB158-F-5(5), IPB180-F12(1), IPB180-F-12(2), IPB180-F-12(3), IPB180-F-12(4), IPB180-F-12(5), IPB180-F-6-1-1(1), IPB180-F-6-1-1(2), IPB180-F-6-1-1(3), IPB180-F-6-1-1(4), dan IPB180-F-6-11(5). Setiap perlakuan diuji pada $\mathrm{MK}$ dan $\mathrm{MH}$, dan ulangan tersarang pada musim. Percobaan ditata dalam rancangan kelompok lengkap teracak (RKLT) dengan empat ulangan di tiap musim.

Benih yang ditanam pada musim kedua dipastikan berasal dari tanaman musim pertama dari ember yang sama. Setiap perlakuan dalam satu ulangan menggunakan tiga tanaman. Pengamatan dilakukan terhadap karakter panjang malai (PM), jumlah gabah total per malai (JGT), jumlah cabang primer (JCP), panjang cabang primer (PCP), jumlah cabang sekunder (JCS), panjang cabang sekunder (PCS), dan jumlah cabang tersier (JCT). Panjang malai diukur mulai dari leher malai hingga gabah terakhir pada ujung malai, jumlah gabah total per malai merupakan jumlah seluruh gabah dari cabang primer, cabang sekunder, maupun cabang tersier. Jumlah cabang primer dihitung berdasarkan jumlah cabang yang keluar langsung dari aksis utama malai, sedangkan panjang cabang primer diukur dari pangkal tempat keluarnya cabang primer pada aksis malai sampai gabah paling ujung pada cabang primer. Jumlah cabang sekunder merupakan jumlah seluruh cabang yang keluar dari cabang primer, dan panjang cabang sekunder diukur dari pangkal cabang sekunder sampai gabah paling pada ujung cabang sekunder. Jumlah cabang tersier merupakan jumlah seluruh cabang yang keluar dari cabang sekunder dalam satu malai.

Perbedaan antara genotipe IPB180-F-12 dan IPB180F-6-1-1 terletak pada percabangan malai. Malai genotipe IPB180-F-12 memiliki percabangan sedikit, sedangkan genotipe IPB180-F-6-1-1 mempunyai banyak percabangan, termasuk cabang tersier malai (Gambar 1).

Penanaman dilakukan dalam ember dengan media tanam tanah sawah berasal dari Kebun Percobaan Babakan, IPB. Volume ember untuk percobaan kira-kira 5 liter dan diisi penuh media tanam dengan menyisakan ruang \pm 2 $\mathrm{cm}$ dari mulut ember. Media tanam digemburkan sebelum penanaman. Biji dari masing-masing malai disemai dan ditanam satu bibit per ember pada umur 21 hari setelah semai dan jika terjadi pertumbuhan yang tidak normal dilakukan penggantian dari pertanaman cadangan.

Pemeliharaan yang dilakukan meliputi pemupukan $\mathrm{N}$ dalam bentuk urea, $\mathrm{P}$ dalam bentuk SP36 dan K dalam bentuk KCl. Urea diberikan dengan dosis $200 \mathrm{~kg} \mathrm{ha}^{-1}(96$ $\mathrm{kg} \mathrm{N} \mathrm{ha}^{-1}$ ), SP36 dengan dosis $300 \mathrm{~kg} \mathrm{ha}^{-1}\left(108 \mathrm{~kg} \mathrm{P}_{2} \mathrm{O}_{5} \mathrm{ha}^{-1}\right)$ dan $\mathrm{KCl} 150 \mathrm{~kg} \mathrm{ha}^{-1}\left(90 \mathrm{~kg} \mathrm{~K}_{2} \mathrm{O} \mathrm{ha}^{-1}\right)$. Pupuk SP36 dan $\mathrm{KCl}$ diberikan seluruhnya pada saat tanam, dan sepertiga dosis pupuk urea. Pemupukan kedua dan ketiga dilakukan pada saat tanaman berumur 14 hari dan 28 setelah tanam (HST) masing-masing sepertiga dosis pupuk urea. Setiap pemberian pupuk disertai dengan penggemburan media tanam untuk mempermudah perkembangan perakaran. Pemeliharaan 

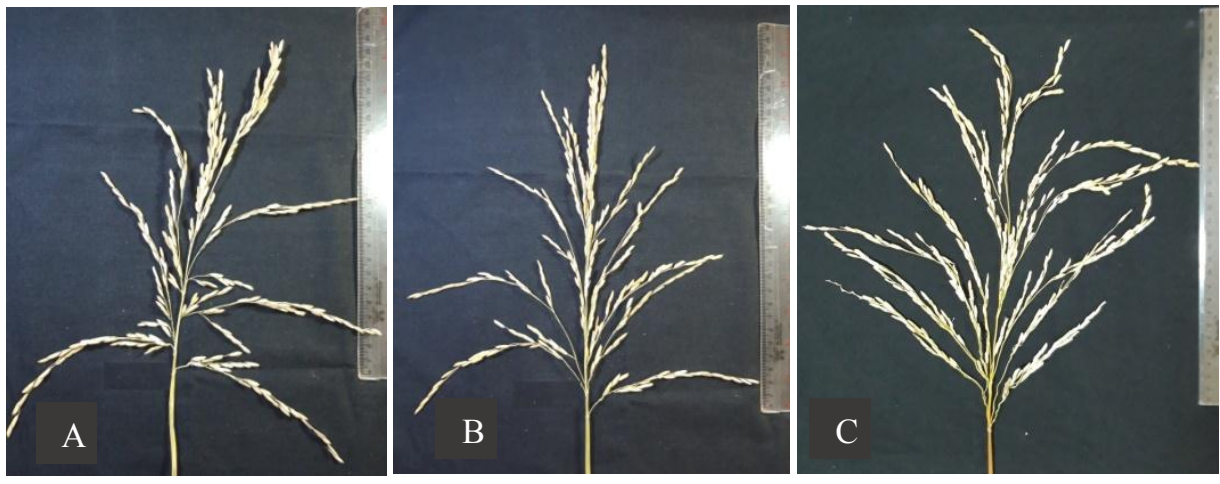

Gambar 1. Penampilan malai genotipe yang digunakan dalam percobaan. A. IPB158-5, B. IPB180-12, C. IPB180-6-1-1

yang lain yaitu penyiangan gulma, pengendalian organisme pengganggu tanaman, dan penyiraman, dilakukan sesuai kondisi di lapangan.

Analisis ragam gabungan dilakukan pada karakter yang mempunyai kesamaan ragam pada $\mathrm{MK}$ dan $\mathrm{MH}$, atau jika nilai koefisien keragaman (KK) pada MK dan $\mathrm{MH} \leq 20 \%$. Analisis homogenitas ragam $\mathrm{MK}$ dan $\mathrm{MH}$ dilakukan menggunakan uji $\mathrm{F}$, karena hanya terdapat dua unit percobaan. Nilai $\mathrm{F}$ hitung diperoleh dengan cara membagi kuadrat tengah galat yang bernilai besar dengan kuadrat tengah galat yang bernilai kecil, dan selanjutnya membandingkan nilai $\mathrm{F}$ hitung tersebut dengan $\mathrm{F}$ tabel pada taraf 5\%. Analisis ragam setiap musim terhadap seluruh karakter yang diamati dilakukan secara terpisah, dan jika terdapat perbedaan berdasar nilai $\mathrm{F}$, maka dilakukan uji lanjut berdasarkan uji Duncan pada taraf 5\%. Perbedaan penampilan karakter percabangan malai antara MK dan $\mathrm{MH}$ dianalisis menggunakan uji-t pada taraf 5\%. Pada karakter yang menunjukkan ragam tidak homogen pada MH dan MK dilakukan analisis ragam pada masing-masing percobaan. Analisis dilakukan menggunakan perangkat lunak STAR dari IRRI dan Minitab 15.

\section{HASIL DAN PEMBAHASAN}

Tabel 1 menunjukkan bahwa syarat untuk dilakukannya analisis ragam gabungan antara $\mathrm{MK}$ dan $\mathrm{MH}$ telah terpenuhi (nilai $\mathrm{p} \geq 0.05$ atau nilai $\mathrm{KK} \leq 20 \%$ ) pada karakter panjang malai, jumlah cabang primer, panjang cabang primer, dan panjang cabang sekunder. Analisis ragam gabungan terhadap 15 perlakuan menunjukkan bahwa musim berpengaruh nyata sampai sangat nyata terhadap percabangan malai kecuali panjang cabang sekunder. Ulangan dalam musim tidak berpengaruh nyata terhadap percabangan malai kecuali pada karakter panjang cabang primer. Pada hasil analisis ini, genotipe dan interaksi genotipe $\times$ musim berpengaruh nyata sampai sangat nyata terhadap karakter panjang malai, jumlah cabang primer, panjang cabang primer, dan panjang cabang sekunder (Tabel 1). Bose et al. (2012) menyatakan bahwa kontribusi pengaruh musim dapat ditunjukkan oleh nilai kuadrat tengah yang nyata sampai sangat nyata. Sengwayo et al. (2018) mengemukakan bahwa jika proporsi komponen $\mathrm{G} \times \mathrm{E}$ besar, maka diduga bahwa keragaman pada karakter tersebut lebih disebabkan oleh interaksi genotipe $\times$ lingkungan.

Gambar 2 menjelaskan terdapatnya interaksi genotipe $\times$ musim pada karakter percabangan malai. Terdapatnya interaksi genotipe $\times$ musim dapat diketahui dari respon setiap genotipe yang membentuk sudut yang berbeda-beda. Genotipe IPB158-F-5 mempunyai penampilan percabangan malai yang stabil pada kedua musim, sedangkan genotipe tipe baru IPB180-F-12 dan IPB180-F-6-1-1 berpenampilan lebih baik pada MK. Menurut Bose et al. (2012), perbedaan selisih penampilan antar genotipe pada lingkungan tumbuh yang berbeda dapat terjadi karena adanya interaksi genotipe dengan lingkungan tumbuhnya. Hasil penelitian Jayaningsih et al. (2019) menunjukkan bahwa terdapat interaksi $\mathrm{G} \times \mathrm{E}$ yang nyata pada karakter panjang malai, jumlah cabang primer malai, dan jumlah gabah total per malai.

Secara langsung maupun tidak langsung, karakter percabangan malai berkorelasi dengan hasil padi. Hasil padi yang berkorelasi positif nyata dengan panjang malai, jumlah cabang sekunder, jumlah gabah total per malai, dan jumlah gabah isi per malai dilaporkan oleh Bagheri et al. (2011), sedangkan Jayaningsih et al. (2019) melaporkan bahwa jumlah gabah total per malai berkorelasi positif nyata dengan panjang malai, panjang aksis malai, jumlah cabang sekunder, panjang cabang primer, dan kerapatan gabah per cabang primer. Faktor lingkungan yang dapat mempengaruhi percabangan malai tersebut antara lain suhu udara, kondisi pengairan dan penyinaran matahari. Hasil penelitian Kato dan Katsura (2010) menunjukkan bahwa arsitektur malai suatu genotipe padi yang ditanam pada kondisi pengairan berbeda menunjukkan respon berbeda. Kondisi tersebut membuktikan terdapatnya interaksi $\mathrm{G} \times \mathrm{E}$ pada karakter percabangan malai. Faktor lain yang diduga menyebabkan penampilan genotipe tipe baru IPB180-F-12 dan IPB180-F6-1-1 berpenampilan lebih baik pada $\mathrm{MK}$ adalah penyinaran matahari. Proses fotosintesis pada MK lebih tinggi daripada MH karena pada MK terdapat penyinaran matahari penuh sehingga fotosintat yang dihasilkan lebih banyak. Cantila dan Quitel (2017) melaporkan bahwa pada MK rata-rata curah hujan dan kelembaban relatif lebih rendah dibandingkan $\mathrm{MH}$, sedangkan temperatur dan radiasi matahari lebih tinggi. 
Tabel 1. Rekapitulasi kuadrat tengah analisis ragam gabungan karakter percabangan malai padi pada $\mathrm{MK}$ dan $\mathrm{MH}$

\begin{tabular}{|c|c|c|c|c|c|c|c|}
\hline \multirow[b]{2}{*}{ Karakter } & \multirow{2}{*}{$\begin{array}{l}\text { Nilai } \mathrm{p} \\
\text { homogenitas } \\
\text { ragam }\end{array}$} & \multirow[b]{2}{*}{ KK $(\%)$} & \multicolumn{5}{|c|}{ Sumber keragaman } \\
\hline & & & Musim & $\begin{array}{l}\text { Ulangan/ } \\
\text { musim }\end{array}$ & Genotipe & $\begin{array}{l}\text { Genotipe } \times \\
\text { musim }\end{array}$ & Galat \\
\hline PM & 0.001 & 8.35 & $165.857 * *$ & $3.443 * *$ & $18.578 * *$ & $4.881 * *$ & 1.069 \\
\hline JCP & 0.338 & 11.34 & $2.4281 * *$ & $0.349 \mathrm{tn}$ & $14.667 * *$ & $0.640 *$ & 0.231 \\
\hline РCP & 0.008 & 9.96 & $40.5937 * *$ & $2.137 * *$ & $8.687 * *$ & $1.801 * *$ & 0.392 \\
\hline PCS & 0.947 & 7.96 & $0.015 \mathrm{tn}$ & $0.058 *$ & $0.448 * *$ & $0.092 * *$ & 0.022 \\
\hline
\end{tabular}

Keterangan: $\mathrm{PM}=$ panjang malai; $\mathrm{JCP}=$ jumlah cabang primer; $\mathrm{PCP}=$ panjang cabang primer; $\mathrm{JCS}=$ jumlah cabang sekunder; $*=$ berpengaruh nyata pada $\mathrm{p}<0.05 ; * *$ berpengaruh nyata pada $\mathrm{p}<0.01 ; \mathrm{tn}=$ tidak berpengaruh nyata
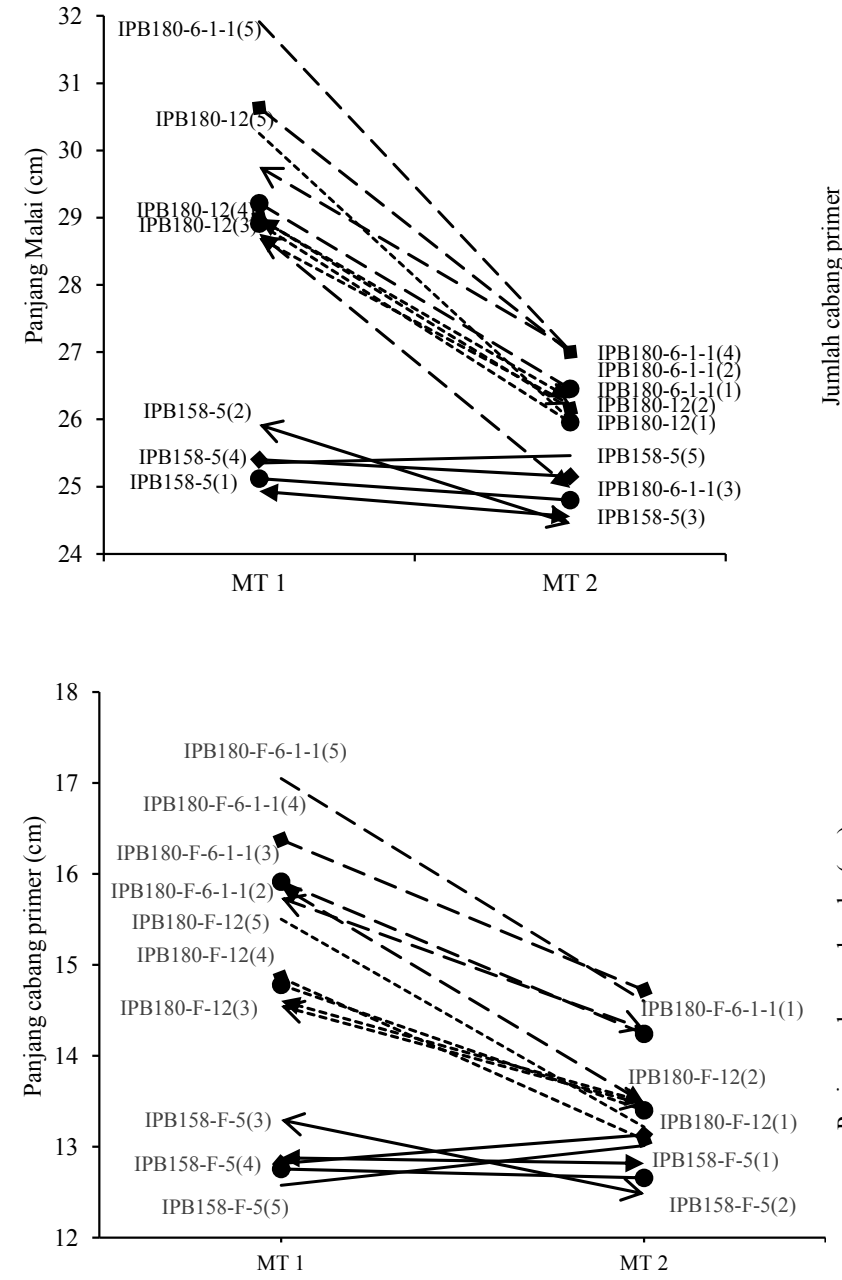
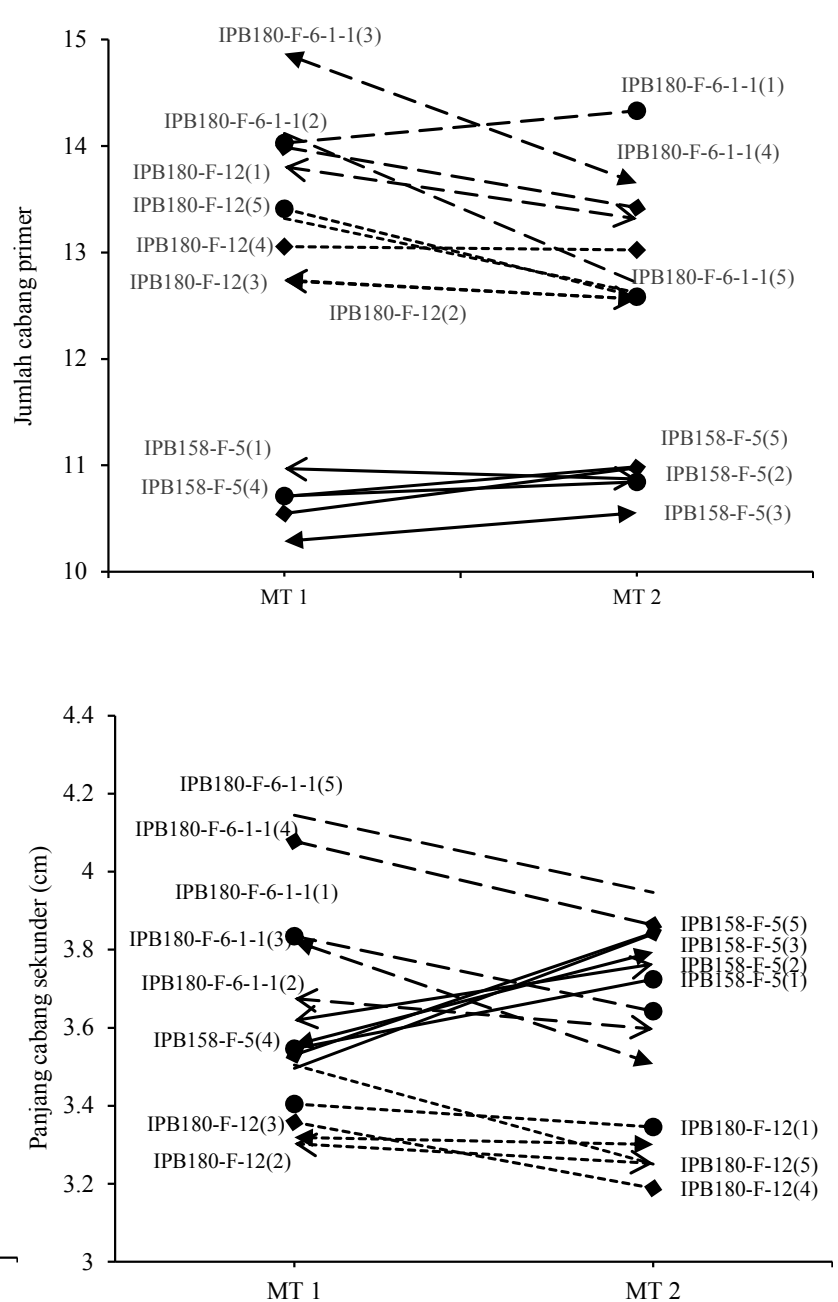

Gambar 2. Interaksi genotipe $\times$ musim pada karakter percabangan malai

Kondisi curah hujan yang lebih rendah dan suhu yang lebih tinggi pada MK daripada MH juga dilaporkan oleh Santosa dan Suryanto (2015).

Berdasarkan uji-t, perbedaan penampilan antara MK dan $\mathrm{MH}$ pada karakter panjang malai ditunjukkan oleh IPB158-F-5(2), IPB-180-F-12(4), IPB-180-F-12(5), IPB180-F-6-1-1(1), IPB180-F-6-1-1(2), IPB180-F-6-11(3), IPB180-F-6-1-1(4), dan IPB180-F-6-1-1(5). Perbedaan jumlah gabah total antara $\mathrm{MK}$ dan $\mathrm{MH}$ terlihat pada genotipe
IPB180-F-12(5), IPB180-F-6-1-1(2), IPB180-F-6-1-1(3), dan IPB180-F-6-1-1(5). Perbedaan pada karakter jumlah cabang primer ditunjukkan oleh genotipe IPB-180-F-12(5), IPB180-F-6-1-1(3), dan IPB180-F-6-1-1(4), sedangkan pada karakter panjang cabang primer terdapat perbedaan pada genotipe IPB-180-F-12(5), IPB180-F-6-1-1(3), dan IPB180-F-6-1-1(5). Perbedaan jumlah cabang sekunder ditunjukkan oleh genotipe IPB180-F-12(5), IPB180-F-61-1(2), IPB180-F-6-1-1(3), dan IPB180-F-6-1-1(5). Pada 
karakter panjang cabang sekunder terlihat perbedaan MK dan MH pada genotipe IPB158-F-5(5), IPB-180-F-12(5), dan IPB180-F-6-1-1(3), dan pada karakter jumlah cabang tersier perbedaan terdapat pada genotipe IPB158-F-5(5), IPB-180-F-12(3), IPB-180-F-12(5), dan IPB180-F-6-11(3) (Tabel 2). Penampilan karakter panjang malai, jumlah gabah total, jumlah cabang primer, panjang cabang primer, jumlah cabang sekunder, dan panjang cabang sekunder genotipe IPB180-F-12 pada MK terlihat secara nyata lebih baik daripada $\mathrm{MH}$, sedangkan pada genotipe IPB180-F6-1-1 seluruh karakter percabangan malai menunjukkan penampilan yang secara nyata lebih baik pada MK.

Nilai rata-rata dan standar deviasi karakter percabangan malai dari setiap perlakuan pada MK dan MH disajikan pada Tabel 2. Pada MK dan MH, genotipe IPB158-F-5 dan IPB180-F-12 tidak menunjukkan perbedaan percabangan

Tabel 2. Nilai rata-rata dan standar deviasi karakter percabangan 15 malai padi pada MK dan MH serta perbandingan karakter percabangan malai tiga genotipe pada $\mathrm{MK}$ dan $\mathrm{MH}$

\begin{tabular}{|c|c|c|c|c|c|c|c|c|}
\hline Genotipe & & PM $(\mathrm{cm})$ & JGT & $\mathrm{JCP}$ & $\mathrm{PCP}(\mathrm{cm})$ & JCS & $\mathrm{PCS}(\mathrm{cm})$ & JCT \\
\hline \multirow[t]{2}{*}{ IPB158-F-5(1) } & MK & $25.12 \pm 1.45 \mathrm{~d}$ & $193.74 \pm 25.18 \mathrm{e}$ & $10.71 \pm 0.63 \mathrm{e}$ & $12.76 \pm 0.73 f$ & $36.87 \pm 4.69 \mathrm{e}$ & $3.55 \pm 0.09 \mathrm{cdef}$ & $3.77 \pm 2.08 \mathrm{c}$ \\
\hline & $\mathrm{MH}$ & $24.80 \pm 0.31 \mathrm{~cd}$ & $198.07 \pm 12.24 \mathrm{def}$ & $10.84 \pm 0.21 \mathrm{e}$ & $12.66 \pm 0.28 \mathrm{~d}$ & $37.72 \pm 2.69 \mathrm{cde}$ & $3.72 \pm 0.05 \mathrm{abcd}$ & $3.33 \pm 1.99 \mathrm{abc}$ \\
\hline \multirow[t]{2}{*}{ IPB158-F-5(2) } & MK & $25.92 \pm 0.44 d$ & $200.56 \pm 9.14 \mathrm{e}$ & $10.97 \pm 0.17 \mathrm{e}$ & $13.30 \pm 0.49 \mathrm{f}$ & $38.34 \pm 1.39 \mathrm{e}$ & $3.62 \pm 0.14 \mathrm{bcd}$ & $3.75 \pm 1.80 \mathrm{c}$ \\
\hline & $\mathrm{MH}$ & $24.45 \pm 1.10 \mathrm{~d}$ & $195.69 \pm 14.57 \mathrm{ef}$ & $10.84 \pm 0.44 \mathrm{e}$ & $12.48 \pm 0.72 \mathrm{~d}$ & $37.23 \pm 2.22 \mathrm{de}$ & $3.76 \pm 0.14 \mathrm{abc}$ & $3.31 \pm 2.15 \mathrm{abc}$ \\
\hline \multirow[t]{2}{*}{ IPB158-F-5(3) } & MK & $24.93 \pm 0.76 \mathrm{~d}$ & $176.39 \pm 17.39 \mathrm{e}$ & $10.29 \pm 0.23 \mathrm{e}$ & $12.88 \pm 0.58 \mathrm{f}$ & $33.51 \pm 2.97 \mathrm{e}$ & $3.56 \pm 0,17 \mathrm{cde}$ & $3.16 \pm 1.47 \mathrm{c}$ \\
\hline & $\mathrm{MH}$ & $24.56 \pm 1.11 \mathrm{~d}$ & $187.67 \pm 18.40 \mathrm{f}$ & $10.56 \pm 0.29 \mathrm{e}$ & $12.82 \pm 0.59 \mathrm{~d}$ & $35.56 \pm 3.42 \mathrm{e}$ & $3.79 \pm 0.13 \mathrm{abc}$ & $4.07 \pm 1.63 \mathrm{abc}$ \\
\hline \multirow[t]{2}{*}{ IPB158-F-5(4) } & MK & $25.40 \pm 2.11 \mathrm{~d}$ & $185.69 \pm 24.36 \mathrm{e}$ & $10.55 \pm 0.65 \mathrm{e}$ & $12.82 \pm 1.08 \mathrm{f}$ & $35.59 \pm 4.52 \mathrm{e}$ & $3.53 \pm 0.23 \mathrm{cdef}$ & $2.64 \pm 1.91 \mathrm{c}$ \\
\hline & $\mathrm{MH}$ & $25.15 \pm 0.66 \mathrm{bcd}$ & $204.65 \pm 8.44 \mathrm{def}$ & $10.98 \pm 0.32 \mathrm{e}$ & $13.13 \pm 0.51 \mathrm{~cd}$ & $38.07 \pm 1.34 \mathrm{bcde}$ & $3.84 \pm 0.10 \mathrm{ab}$ & $4.48 \pm 2.23 \mathrm{abc}$ \\
\hline \multirow[t]{2}{*}{ IPB158-F-5(5) } & MK & $25.35 \pm 0.87 d$ & $181.62 \pm 13.54 \mathrm{e}$ & $10.71 \pm 0.55 \mathrm{e}$ & $12.58 \pm 0.36 \mathrm{f}$ & $35.02 \pm 3.07 \mathrm{e}$ & $3.50 \pm 0.06 \mathrm{cdef}$ & $2.63 \pm 0.95 c$ \\
\hline & $\mathrm{MH}$ & $25.46 \pm 1.08 \mathrm{abcd}$ & $208.53 \pm 15.76 \mathrm{cdef}$ & $10.99 \pm 0.11 \mathrm{e}$ & $13.01 \pm 0.91 \mathrm{~d}$ & $38.91 \pm 2.65 \mathrm{bcde}$ & $3.84 \pm 0.24 a b$ & $5.26 \pm 2.15 \mathrm{abc}$ \\
\hline \multirow[t]{2}{*}{ Rata-rata } & MK & $25.34 \mathrm{c}$ & $187.60 \mathrm{c}$ & $10.65 \mathrm{c}$ & $12.87 \mathrm{c}$ & $35.87 \mathrm{c}$ & $3.55 \mathrm{~b}$ & $3.19 \mathrm{~b}$ \\
\hline & $\mathrm{MH}$ & $24.89 \mathrm{~b}$ & $198.90 \mathrm{c}$ & $10.85 \mathrm{c}$ & $12.82 \mathrm{c}$ & $37.50 \mathrm{c}$ & $3.79 \mathrm{a}$ & $4.09 \mathrm{a}$ \\
\hline \multirow[t]{2}{*}{ IPB180-F-12(1) } & MK & $28.91 \pm 1.32 \mathrm{bc}$ & $276.05 \pm 34.24 \mathrm{~cd}$ & $13.41 \pm 0.53 \mathrm{bcd}$ & $14.78 \pm 0.84 \mathrm{de}$ & $52.14 \pm 5.38 \mathrm{~cd}$ & $3.40 \pm 0.24 \mathrm{def}$ & $3.20 \pm 2.59 \mathrm{c}$ \\
\hline & $\mathrm{MH}$ & $25.96 \pm 1.44 \mathrm{abcd}$ & $223.95 \pm 13.18$ bcdef & $12.58 \pm 0.39 \mathrm{~d}$ & $13.40 \pm 0.73 \mathrm{bcd}$ & $41.70 \pm 1.97 \mathrm{bcde}$ & $3.35 \pm 0.15 \mathrm{ef}$ & $1.47 \pm 1.34 \mathrm{bc}$ \\
\hline \multirow[t]{2}{*}{ IPB180-F-12(2) } & MK & $28.69 \pm 0.92 \mathrm{c}$ & $272.97 \pm 16.89 \mathrm{~cd}$ & $12.74 \pm 0.69 \mathrm{~d}$ & $14.55 \pm 0.59 \mathrm{e}$ & $52.27 \pm 3.22 \mathrm{~cd}$ & $3.30 \pm 0.12 \mathrm{f}$ & $2.25 \pm 1.05 \mathrm{c}$ \\
\hline & MH & $26.23 \pm 1.68 \mathrm{abcd}$ & $231.99 \pm 38.05$ bcde & $12.56 \pm 0.66 \mathrm{~d}$ & $13.46 \pm 1.12 \mathrm{bcd}$ & $43.31 \pm 7.62 \mathrm{bcd}$ & $3.25 \pm 0.20 \mathrm{f}$ & $1.40 \pm 1.23 \mathrm{bc}$ \\
\hline \multirow[t]{2}{*}{ IPB180-F-12(3) } & MK & $28.98 \pm 0.83 b c$ & $265.38 \pm 24.33 \mathrm{~d}$ & $12.73 \pm 0.49 \mathrm{~d}$ & $14.61 \pm 0.69 \mathrm{e}$ & $50.51 \pm 3.88 \mathrm{~d}$ & $3.32 \pm 0.18 \mathrm{ef}$ & $2.81 \pm 1.43 c$ \\
\hline & $\mathrm{MH}$ & $26.31 \pm 1.52 \mathrm{abcd}$ & $235.38 \pm 24.57 \mathrm{bcde}$ & $12.56 \pm 0.50 \mathrm{~d}$ & $13.50 \pm 0.71 \mathrm{bcd}$ & $43.83 \pm 5.18 \mathrm{bcd}$ & $3.30 \pm 0.13 \mathrm{ef}$ & $1.25 \pm 1.22 \mathrm{c}$ \\
\hline \multirow[t]{2}{*}{ IPB180-F-12(4) } & MK & $28.99 \pm 0.80 b c$ & $283.85 \pm 25.94 \mathrm{~cd}$ & $13.05 \pm 0.59 \mathrm{~d}$ & $14.86 \pm 0.60 \mathrm{cde}$ & $53.98 \pm 4.01 \mathrm{~cd}$ & $3.35 \pm 0.16 \mathrm{ef}$ & $3.32 \pm 2.33 \mathrm{c}$ \\
\hline & $\mathrm{MH}$ & $26.16 \pm 0.58 \mathrm{abcd}$ & $239.76 \pm 18.53 \mathrm{bcd}$ & $13.02 \pm 0.43 \mathrm{bcd}$ & $13.08 \pm 0.65 \mathrm{~d}$ & $45.21 \pm 3.42 b$ & $3.19 \pm 0.12 \mathrm{f}$ & $1.06 \pm 0.78 \mathrm{c}$ \\
\hline \multirow[t]{2}{*}{ IPB180-F-12(5) } & MK & $30.25 \pm 0.20 \mathrm{abc}$ & $309.82 \pm 13.25 \mathrm{c}$ & $13.32 \pm 0.34 \mathrm{~cd}$ & $15.50 \pm 0.39$ bcde & $58.49 \pm 1.74 \mathrm{c}$ & $3.5 \pm 0.11 \mathrm{cdef}$ & $5.96 \pm 2.91 \mathrm{c}$ \\
\hline & $\mathrm{MH}$ & $25.99 \pm 0.34 \mathrm{abcd}$ & $228.96 \pm 7.89$ bcdef & $12.62 \pm 0.29 \mathrm{~d}$ & $13.22 \pm 0.30 \mathrm{bcd}$ & $43.36 \pm 2.58 \mathrm{bcd}$ & $3.25 \pm 0.08 f$ & $0.84 \pm 0.48 c$ \\
\hline \multirow[t]{2}{*}{ Rata-rata } & MK & $29.17 b$ & $281.61 b$ & $13.05 \mathrm{~b}$ & $14.86 \mathrm{~b}$ & $53.48 \mathrm{~b}$ & $3.38 \mathrm{c}$ & $3.51 \mathrm{~b}$ \\
\hline & $\mathrm{MH}$ & $26.13 \mathrm{a}$ & $232.01 b$ & $12.67 \mathrm{~b}$ & $13.33 b$ & $43.48 b$ & $3.27 \mathrm{~b}$ & $1.21 \mathrm{a}$ \\
\hline \multirow[t]{2}{*}{ IPB180-F-6-1-1(1) } & MK & $29.22 \pm 1.15 b c$ & $384.42 \pm 42.55 b$ & $14.03 \pm 0.73 b c$ & $15.91 \pm 0.40 \mathrm{bc}$ & $67.03 \pm 5.59 b$ & $3.83 \pm 0.10 \mathrm{~b}$ & $20.37 \pm 8.91 b$ \\
\hline & $\mathrm{MH}$ & $26.45 \pm 1.82 \mathrm{abc}$ & $313.95 \pm 41.04 \mathrm{a}$ & $14.33 \pm 0.29 \mathrm{a}$ & $14.24 \pm 1.11 \mathrm{abc}$ & $56.82 \pm 6.41 \mathrm{a}$ & $3.64 \pm 0.27 \mathrm{bcd}$ & $8.57 \pm 6.38 \mathrm{a}$ \\
\hline \multirow[t]{2}{*}{ IPB180-F-6-1-1(2) } & MK & $29.76 \pm 0.86 b c$ & $304.19 \pm 39.33 \mathrm{~cd}$ & $13.80 \pm 0.53 \mathrm{bc}$ & $15.73 \pm 0.89 \mathrm{bcd}$ & $52.84 \pm 5.70 \mathrm{~cd}$ & $3.68 \pm 0.20 b c$ & $7.64 \pm 4.33 \mathrm{c}$ \\
\hline & $\mathrm{MH}$ & $27.05 \pm 1.04 a$ & $248.83 \pm 25.96 b c$ & $13.32 \pm 0.45 \mathrm{bcd}$ & $14.29 \pm 0.59 \mathrm{ab}$ & $43.68 \pm 4.97 \mathrm{bcd}$ & $3.60 \pm 0.12 \mathrm{~cd}$ & $3.66 \pm 1.91 \mathrm{abc}$ \\
\hline \multirow[t]{2}{*}{ IPB180-F-6-1-1(3) } & MK & $28.76 \pm 0.25 c$ & $434.55 \pm 42.35 \mathrm{a}$ & $14.87 \pm 0.41 \mathrm{a}$ & $15.87 \pm 0.24 \mathrm{bcd}$ & $76.21 \pm 6.85 a$ & $3.82 \pm 0.06 \mathrm{~b}$ & $26.27 \pm 10.81 \mathrm{a}$ \\
\hline & $\mathrm{MH}$ & $24.98 \pm 0.74 \mathrm{~cd}$ & $305.68 \pm 24.58 \mathrm{a}$ & $13.65 \pm 0.37 \mathrm{~b}$ & $13.48 \pm 0.50 \mathrm{bcd}$ & $57.24 \pm 4.23 \mathrm{a}$ & $3.51 \pm 0.07 \mathrm{de}$ & $7.11 \pm 2.67 a b$ \\
\hline \multirow[t]{2}{*}{ IPB180-F-6-1-1(4) } & MK & $30.63 \pm 1.35 \mathrm{ab}$ & $309.27 \pm 24.68 \mathrm{c}$ & $13.99 \pm 0.19 b c$ & $16.37 \pm 0.54 \mathrm{ab}$ & $51.69 \pm 4.46 \mathrm{~cd}$ & $4.08 \pm 0.15 \mathrm{a}$ & $4.74 \pm 3.39 \mathrm{c}$ \\
\hline & $\mathrm{MH}$ & $27.00 \pm 1.02 \mathrm{ab}$ & $260.41 \pm 40.52 \mathrm{~b}$ & $13.42 \pm 0.29 b c$ & $14.72 \pm 0.81 \mathrm{a}$ & $44.69 \pm 8.17 \mathrm{bc}$ & $3.86 \pm 0.13 \mathrm{ab}$ & $2.17 \pm 1.57 \mathrm{bc}$ \\
\hline \multirow[t]{2}{*}{ IPB180-F-6-1-1(5) } & MK & $31.91 \pm 0.85 a$ & $350.23 \pm 19.98 b$ & $14.12 \pm 0.20 \mathrm{~b}$ & $17.05 \pm 0.66 \mathrm{a}$ & $58.12 \pm 3.72 \mathrm{c}$ & $4.14 \pm 0.22 \mathrm{a}$ & $4.63 \pm 2.93 \mathrm{c}$ \\
\hline & $\mathrm{MH}$ & $27.02 \pm 1.53 a b$ & $247.61 \pm 37.44 b c$ & $12.72 \pm 1.20 \mathrm{~cd}$ & $14.60 \pm 1.32 \mathrm{a}$ & $42.05 \pm 5.22 \mathrm{bcde}$ & $3.95 \pm 0.19 \mathrm{a}$ & $2.12 \pm 1.98 \mathrm{bc}$ \\
\hline \multirow[t]{2}{*}{ Rata-rata } & MK & $30.06 \mathrm{a}$ & $356.53 \mathrm{a}$ & $14.16 \mathrm{a}$ & $16.19 \mathrm{a}$ & $61.18 \mathrm{a}$ & $3.91 \mathrm{a}$ & $12.73 \mathrm{a}$ \\
\hline & MH & $26.50 \mathrm{a}$ & $275.30 \mathrm{a}$ & $13.49 \mathrm{a}$ & $14.27 \mathrm{a}$ & $48.90 \mathrm{a}$ & $3.71 \mathrm{a}$ & $4.71 \mathrm{a}$ \\
\hline
\end{tabular}

Keterangan: Nilai yang diikuti oleh huruf yang sama dan kolom yang sama pada musim yang sama tidak berbeda berdasarkan uji jarak berganda Duncan taraf 5\%. Nilai yang dicetak tebal pada kolom yang sama menunjukkan perbedaan antara MK dan MH menurut uji t taraf 5\%. Nilai rata-rata genotipe pada musim yang sama yang diikuti oleh huruf yang sama tidak berbeda menurut uji Duncan taraf $5 \%$. PM = panjang malai; JGT $=$ jumlah gabah total; JCP = jumlah cabang primer; PCP = panjang cabang primer; JCS = jumlah cabang sekunder; PCS $=$ panjang cabang sekunder; JCT = jumlah cabang tersier 
malai di dalam genotipe. Artinya pada kedua genotipe tersebut, karakter percabangan malai di dalam genotipe tidak beragam meskipun berasal dari malai yang berbeda. Sebaliknya, genotipe IPB180-F-6-1-1 menunjukkan keragaman di dalam genotipe pada seluruh karakter percabangan malai yang diamati. Genotipe IPB180-F-6-1-1 lebih baik dibandingkan IPB180-F-12 maupun IPB158-F-5 pada MK, demikian juga pada MH (Tabel 2). Hal tersebut memberikan informasi bahwa genotipe berpengaruh terhadap percabangan malai. Hasil tersebut sejalan dengan hasil penelitian Rahayu et al. (2018a), bahwa genotipe berpengaruh nyata terhadap karakter percabangan malai. Setelah genotipe IPB180-F-6-1-1, genotipe IPB180-F-12 terlihat lebih baik dibandingkan genotipe IPB158-F-5 pada karakter panjang malai, jumlah gabah total, jumlah cabang primer, panjang cabang primer, dan jumlah cabang malai sekunder. Jumlah cabang tersier genotipe IPB180-F-12 tidak berbeda dengan jumlah cabang tersier genotipe IPB158-F-5. Panjang malai genotipe IPB180-F-12 tidak berbeda dengan panjang malai genotipe IPB180-F-6-1-1 pada $\mathrm{MH}$, demikian juga pada karakter jumlah cabang tersier. Rata-rata jumlah gabah total per malai genotipe IPB180-F-12 lebih rendah 43.3 butir dibandingkan genotipe IPB180-F-6-1-1, namun lebih tinggi 33.1 butir dibandingkan genotipe IPB158-F-5. Demikian juga pada karakter jumlah cabang primer, panjang cabang primer, dan jumlah cabang sekunder, genotipe IPB180-F-12 menunjukkan penampilan yang lebih baik dibandingkan genotipe IPB158-F-5. Hanya pada karakter panjang cabang sekunder, genotipe IPB158-F-5 terlihat menunjukkan penampilan yang lebih baik daripada genotipe IPB180-F-12. Tidak terdapat perbedaan diantara ketiga genotipe pada karakter jumlah cabang tersier. Perbedaan karakter percabangan malai antar genotipe dan antar musim disebabkan oleh pengaruh genotipe, lingkungan dan interaksinya, sehingga genotipe yang mempunyai karakter unggul pada suatu musim dapat berubah rankingnya jika ditanam pada musim yang berbeda. Ranking suatu genotipe dapat berubah-ubah sesuai dengan kondisi lingkungan (Jayaningsih et al., 2019).

\section{KESIMPULAN}

Genotipe dan interaksi genotipe $\times$ musim berpengaruh terhadap karakter percabangan malai padi. Genotipe mempunyai pengaruh terbesar pada karakter panjang malai, jumlah gabah total, jumlah cabang primer, panjang cabang primer, dan panjang cabang primer, diikuti pengaruh interaksi genotipe $\times$ musim. Genotipe IPB158-F-5 menunjukkan penampilan karakter percabangan malai lebih stabil pada kedua musim, sedangkan genotipe IPB180-F-12 dan IPB180-F-6-1-1 berpenampilan lebih baik pada MK.

\section{DAFTAR PUSTAKA}

Alam, M.M., M.R. Karim, J.K. Ladha. 2013. Integrating best management practices for rice with framers' crop management techniques: a potential option for minimizing rice yield gap. Field Crops Res. 144:6268.
Bagheri, N., N.B. Jelodar, A. Pasha. 2011. Path coefficient analysis for yield and yield component in diverse rice (Oryza sativa L.) genotypes. Biharean Biol. 5:32-35.

Baye, T.M., T. Abebe, R.A. Wilke. 2011. Genotypeenvironment interaction and their translational implications. Per Med. 8:59-70.

Bose, L.K., M. Nagaraju, O.N. Singh. 2012. Genotype $\times$ environment interaction and stability analysis of lowland rice genotypes. J. Agric. Sci. 57:1-8.

[BPS] Badan Pusat Statistik Kabupaten Bogor. 2018. Kabupaten Bogor Dalam Angka 2018. Badan Pusat Statistik, Bogor, ID.

[BPS] Badan Pusat Statistik Kabupaten Bogor. 2019. Kabupaten Bogor Dalam Angka 2019. Badan Pusat Statistik, Bogor, ID.

Cantila, A.Y., J.R. Quitel. 2017. Statistical analysis of foreign rice phenotypes under different seasons of the Philippines. J. Adv. Appl. Sci. Res. 1:1-20.

Hastini, T. 2019. Genetik cabang tersier malai padi dan respon percabangan malai terhadap fosfor dan musim. Disertasi. Sekolah Pascasarjana. Institut Pertanian Bogor. Bogor.

Jayaningsih, E.D., W.B. Suwarno, A. Nindita, H. Aswidinnoor. 2019. Interaksi genotipe $\times$ lingkungan pada morfologi malai galur-galur padi (Oryza sativa L.) bermalai lebat. J. Agron. Indonesia 47:240-247.

Islam, M.S., S. Peng, R.M. Visperas, M.S.U. Bhuiya, S.M.A. Hossain, A.W. Julfiquar. 2010. Comparative study on yield and yield attributes of hybrid, inbred, and NPT rice genotypes in a tropical irrigated ecosystem. Bangladesh J. Agril. Res. 35:343-353.

Kato, Y, K. Katsura. 2010. Panicle architecture and grain number in irrigated rice, grown under different water management regimes. Field Crops Res. 117:237244.

Kovi, M.R., X. Bai, D. Mao, Y. Xing. 2011. Impact of seasonal changes on spikelet per panicle, panicle length, and plant height in rice (Oryza sativa L.). Euphytica. 179:319-331.

Laenoi, S., B. Rerkasem, S. Lordkaew, C. Prom-u-thai. 2018. Seasonal variation in grain yield and quality in different rice varieties. Field Crops Res. 221:350357.

Rahayu, S., M. Ghulamahdi, W.B. Suwarno, H. Aswidinnoor. 2018a. Morfologi malai padi (Oryza sativa L.) pada beragam aplikasi pupuk nitrogen. J. Agron. Indonesia. 46:145-152. 
Rahayu,S., W.B. Suwarno, M. Ghulamahdi, H. Aswidinnoor. 2018b. Analysis of panicle morphology traits in F2 and reciprocal F2 populations of rice (Oryza sativa L.). Sabrao J. Breed. Genet. 50:9-24.

Ramadhan, F., 2017. Analisis genetik arsitektur malai padi. Thesis. Sekolah Pascasarjana. Institut Pertanian Bogor. Bogor.

Ramadhan, F., W.B. Suwarno, A. Nindita, H. Aswidinnoor. 2018. Analisis genetik arsitektur malai padi menggunakan dua populasi F2. J. Agron. Indonesia 46:1-8.

Santosa, M., A. Suryanto. 2015. The growth and yield of paddy Ciherang planted in dry and wet season and fertilized with organic and inorganic fertilizers. Agrivita. 37:24-29.

Satoto, Y. Widyastuti, U. Susanto, M.J. Mejaya. 2013. Perbedaan hasil padi antar musim di lahan sawah irigasi. Iptek Tan. Pangan. 8:55-61.
Sengwayo, S., M. Zhou, M. Labuschagne. 2018. Trends and magnitudes of genotype $\times$ environment interaction variance components for yield, quality and agronomic traits among coastal short cycle sugarcane breeding populations. S. Afr. J. Plant Soil. 35:41-50.

Silva, J.V., P. Reidsma, A.G. Laborte, M.K.V. Ittersum. 2017. Explaining rice yields and yield gaps in Central Luzon, Philippines: an application of stochastic frontier analysis and crop modelling. Europ. J. Agron. 82:223-241.

Sumarno, E. Sutisna. 2010. Identification of rice (Oryza sativa L.) varieties suitable for dry season and wet season planting. Indonesian J. Agric. Sci. 11:24-31.

Ulfah, A., W. Sulistya. 2015. Penentuan kriteria awal musim alternatif di wilayah Jawa Timur. J. Meteorologi Geofisika 16:145-153.

Wu, Y.C., S.J. Chang, H.S. Lur. 2016. Effects of field high temperature on grain yield and quality of a subtropical type japonica rice-Pon-Lai rice. Plant Prod. Sci. 19:145-153. 